\title{
KLINIKINIS ATVEJIS: SU SUBARACHNOIDINE GALVOS SMEGENŲ HEMORAGIJA SUSIJUSI TAKOTSUBO KARDIOMIOPATIJA
}

\author{
Tomas Janušonis, Geda Klimavičiūtè, Renata Paškevičiūtė \\ Klaipédos universitetine ligoniné
}

Raktažodžiai: Takotsubo kardiomiopatija, subarachnoidinè hemoragija, kairiojo skilvelio disfunkcija.

\begin{abstract}
Santrauka
Takotsubo (stresinè) kardiomiopatija yra retas neišeminis ūminis kairiojo skilvelio funkcinis sutrikimas, kurị išprovokuoja ūminis fizinis ar psichologinis stresas. Šiame straipsnyje aprašoma 30 metų moteriai pasireiškusi subarachnoidinès galvos smegenų hemoragijos sukelta stresinè kardiomiopatija.
\end{abstract}

\section{Ivadas}

Stresinė kardiomiopatija, dar vadinama Takotsubo kardiomiopatija, pirmą kartą buvo aprašyta Dote ir kt. 1991 metais [1]. Šio sindromo atsiradimą skatina ịvairios stresinès būklès. Jis pasireiškia širdies nepakankamumu, kuriam būdingas tipinis išeminis širdies skausmas, ST segmento pakilimas elektrokardiogramoje (EKG) ir su miokardo pažeidimu susijusių fermentų aktyvumo padidejjimas serume, t. y. ūminio koronarinio sindromo simptomai ir požymiai [2].

Šiame straipsnyje pateikiamas su subarachnoidine galvos smegenu hemoragija susijusios Takotsubo kardiomiopatijos klinikinis atvejis.

\section{Klinikinio atvejo aprašymas}

30 metų moteris buvo pervežta iš rajoninès ligoninès i Klaipėdos universitetinès ligoninès (KUL) Reanimacijos ir intensyvios terapijos skyriu (RITS) dèl sąmonès sutrikimo ir greitai progresuojančio širdies nepakankamumo. Tą dieną darbo vietoje ši iki tol širdies ir kraujagyslių sistemos požiūriu buvusi visiškai sveika moteris staiga neteko sąmonès. I KUL pacientė buvo pervežta kraštutinai sunkios būklès: nesąmoninga (ivvertinimas pagal Glasgow komos skalę 3 balai), intubuota, jai buvo taikoma dirbtinè plaučių ventiliacija (DPV) 100\% deguonimi. Auskultuojant krūtinès ląstą, plaučiuose alsavimas buvo išklausomas abipus, visuose auskultacijos taškuose buvo girdimi ịvairaus pobūdžio drègni karkalai. Arterinio kraujo įsotinimas deguo- nimi $\left(\mathrm{SpO}_{2}\right)$ buvo $70 \%$, širdies susitraukimų dažnis $113 \mathrm{k} . /$ min., arterinis kraujospūdis 100/60 mmHg. Veide buvo cianozè, oda - marmuro spalvos. Buvo atliktas arterinio kraujo dujų tyrimas: $\mathrm{pH} 7,242, \mathrm{pCO}_{2} 57,3 \mathrm{mmHg}, \mathrm{pO}_{2} 47,5$ $\mathrm{mmHg}, \mathrm{ABE}-4,5 \mathrm{mmol} / \mathrm{l}$, laktatų kiekis $2,0 \mathrm{mmol} / \mathrm{l}, \mathrm{F}_{\text {shunt,e }}$ $47,1 \%$. Elektrokardiogramoje buvo sinusine tachikardija.

Troponino I kiekis serume buvo 2,740 $\mu \mathrm{g} / \mathrm{l}$ (norma $0,000-0,028 \mu \mathrm{g} / \mathrm{l})$, po $12 \mathrm{val}$. troponino I kiekis serume buvo $11,638 \mu \mathrm{g} / \mathrm{g} / \mathrm{l}$, smegenų natriuretinio peptido (BNP) kiekis serume $873,8 \mathrm{pg} / \mathrm{ml}$ (norma $0-100 \mathrm{pg} / \mathrm{ml}$ ). Siekiant patikrinti, ar nèra infekcijos, buvo ištirtas $\mathrm{C}$ reaktyviojo baltymo ir prokalcitonino kiekis kraujyje, rodmenys neviršijo normos ribų.

Krūtinès ląstos tiesinejje rentgenogramoje buvo stebima plaučių edema (1 paveikslas).

Buvo atliktas širdies ultragarsinis tyrimas: nustatyta kairiojo skilvelio viršūnès akinezė ir dilatacija, visų sienelių vidurinių segmentų hipokinezé, bazinių segmentų hiperkinezè, širdies išstūmimo frakcija buvo $20 \%$. Atlikus galvos smegenų kompiuterinę tomografiją buvo diagnozuotas subarochnoidinis kraujavimas.

Esant kraštutinai sunkiai būklei, buvo nuspręsta pradèti nuolatini hemodinamikos parametrų stebejjimą transtorakalinès termodiliucijos metodu, naudojant PiCCO monitorių. Tyrimo rezultatai pateikiami 1 lenteleje.

Vertinant PiCCO hemodinamikos rodmenis, širdies ultragarsini tyrimą, sepsio diagnozès paneigimą, diagnozuota galvos smegenų subarachnoidinès hemoragijos sukelta Takotsubo kardiomiopatija. Vadovaujantis Mayo klinikos paskelbtais Takotsubo kardiomiopatijos diagnozavimo kriterijais [3], diagnozei patikslinti buvo atlikta perkutaninè koronarinė intervencija, koronarinès patologijos nebuvo rasta.

Buvo pradèta tikslinè terapija (goal directed therapy). Atsižvelgiant ị PiCCO hemodinaminius rodmenimis, vyraujant širdies nepakankamumo klinikai, nuspręsta skirti vazopresorių dobutaminą (dozè - $10 \mu \mathrm{g} / \mathrm{kg} / \mathrm{min}$.), tęsta DPV, skirta infuzoterapija, Henle kilpoje veikiančių diuretikų, antikoaguliantų (mažos molekulinès masès heparino). 


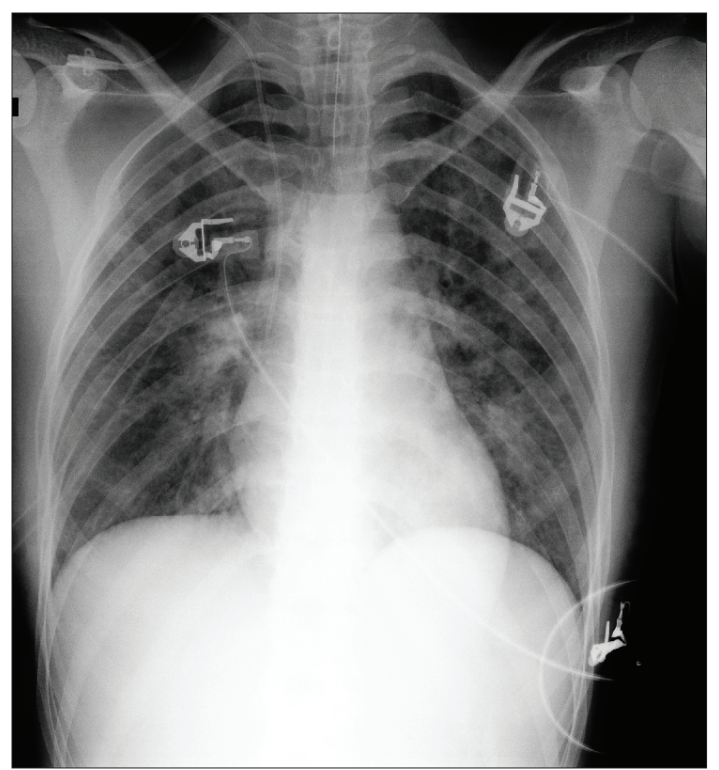

1 paveikslas. Krūtinès ląstos rentgenograma stacionarizavimo dieną

PiCCO hemodinamikos rodmenys sekti 4 paras (1 lentelè), po to, stabilizavusis hemodinamikai, gydymas dobutaminu buvo nutrauktas. Sąmonés būklè negerejo, 4 parą buvo atliktas galvos smegenų angiografijos tyrimas, nustatyta A. communicans ant. maišinè aneurizma, kurios endovaskuliniu būdu embolizuoti nebuvo įmanoma, tad nuspręsta atlikti kraniotomiją ir aneurizmos kakleli klipsuoti. Operacija atlikta 14 gydymo ligonineje parą. Po operacijos hemodinamika buvo stabili, išstūmimo frakcija $35 \%$, pacientè spontaniškai atsimerkè, bandẻ vykdyti elementarius

1 lentelè. Hemodinamikos parametrai, nustatyti transtorakalinės termodiliucijos metodu

\begin{tabular}{|l|c|c|c|c|}
\hline \multicolumn{1}{|c|}{ Parametras } & $\begin{array}{c}\text { Pradiniai } \\
\text { rodmenys }\end{array}$ & $\begin{array}{c}\text { Po 6 } \\
\text { val. }\end{array}$ & $\begin{array}{c}\text { Po 24 } \\
\text { val. }\end{array}$ & 4 parą \\
\hline Širdies indeksas (CI) (1/min./m²) & 2,07 & 3,62 & 3,98 & 3,1 \\
\hline Išstumiamo kraujo tūris (SVI) (ml/m²) & 17 & 4 & 34 & 31 \\
\hline $\begin{array}{l}\text { Sisteminio kraujagyslių rezistentiškumo } \\
\text { indeksas(SVRI) (dyn*sek.*cm*m²) }\end{array}$ & 2025 & 9912 & 1742 & 1798 \\
\hline $\begin{array}{l}\text { Vidutinis arterinis kraujospūdis (MAP) } \\
\text { (mmHg) }\end{array}$ & 61 & 59 & 84 & 82 \\
\hline Bendra išmetimo frakcija(GEF) (\%) & 10 & 11 & 16 & 19 \\
\hline $\begin{array}{l}\text { Bendras galinio diastolinio tūrio } \\
\text { indeksas (GEDI) (ml/m²) }\end{array}$ & 638 & 767 & 850 & 627 \\
\hline $\begin{array}{l}\text { Ekstravaskulinio plaučių vandens } \\
\text { indeksas (ELWI) (ml/kg) }\end{array}$ & 21 & 16 & 16 & 11 \\
\hline Minutinis tūris (CO) (1/min.) & 3,53 & 6,18 & 6,76 & 6,49 \\
\hline $\begin{array}{l}\text { Išstumiamo tūrio svyravimas (SVV) } \\
(\%)\end{array}$ & 11 & 21 & 18 & 13 \\
\hline
\end{tabular}

paliepimus. 20 parą nuo stacionarizavimo buvo nutraukta dirbtinė plaučių ventiliacija. Po mènesio, praleisto ligoninèje, paciente išrašyta reabilitaciniam gydymui. Tolimesnis pacientès stebejjimas nutrūko, duomenų apie kardialines baigtis neturime.

\section{Diskusija}

Takotsubo kardiomiopatija yra retas stresiniu veiksnių sukeliamas ūminis kairiojo skilvelio funkcijos sutrikimas. $90 \%$ atvejų šis sutrikimas pasireiškia moterims, to priežastis nèra žinoma [4]. Manoma, kad 1-2\% atvejų, kai įtariamas ūminis koronarinis sindromas, gali būti susiję su Takotsubo kardiomiopatija [5].

Takotsubo kardiomiopatiją sukelia staiga pasireiškęs ūminis fizinis ar psichologinis stresas. Galimi susiję veiksniai yra netikèta artimojo mirtis, grèsmingos medicininès diagnozès sužinojimas, buitinis smurtas, finansinès problemos, sunkūs sveikatos sutrikimai, pvz., astmos priepuolis, infekcija, ūmine trauma ir sunki operacija [6]. Vienas iš galimų Takotsubo sindromą sukelti galinčių veiksnių yra subarachnoidine hemoragija [7-9]. Prospektyvinio tyrimo metu nustatyta, kad net $18 \%$ subarachnoidinę hemoragiją patyrusių pacientu pasireiškia ultragarsinio tyrimo metu matomų regioninių širdies sienelès judesių sutrikimų [10]. Patfiziologinis stresinès kardiomiopatijos atsiradimo mechanizmas nèra iki galo aiškus. Manoma, kad didžiausią reikšmę turi toksinis katecholaminų poveikis [11, 12]. Reikšmę stresinès kardiomiopatijos atsiradimui gali turèti stambių ar smulkių vainikinių arterijų spazmas, endotelio disfunkcija ir tiesioginis miokardo pažeidimas.

Stresinei kardiomiopatijai diagnozuoti naudojami Mayo klinikos kriterijai [3]. Mūsu pateikiamu klinikiniu atveju paciente atitiko visus keturis diagnozavimo kriterijus: 1) regionine vidurinio širdies sienelès segmento hipokinezé, akinezè ar diskinezè, apimanti daugiau nei vieną epikardinès kraujagyslès maitinamą sriti (patvirtinta širdies ultragarso tyrimu) ir stresinę situaciją išprovokavusio veiksnio buvimas (šiuo atveju tai buvo subarachnoidinè hemoragija); 2) obstrukcinès koronarinès ligos ir angiografinio plokštelès plyšimo nebuvimas (patvirtinta angiografijos tyrimu); 3) nauji elektrokardiogramos pokyčiai (ST segmento pakilimas ir/ arba neigiamo $\mathrm{T}$ dantelio atsiradimas) arba širdies troponino kiekio 
padidejimas (nustatytas troponino I kiekio padidejjimas) bei 4) feochromacitomos ar miokardito nebuvimas (paneigta kliniškai ir laboratoriniais tyrimais).

Aiškių Takotsubo kardiomiopatijos gydymo algoritmų nèra. Skiriamas iprastas komplikaciju gydymas. Tokiems pacientams gali būti naudinga skirti beta blokatoriu [5], tačiau šiuo atveju, atsižvelgiant î kardiovaskulinę būklę (plaučių edemą, šoką), toks gydymas nebuvo skirtas. Taikyta tikslinè terapija (dobutaminas, diuretikai, infuzoterapija, antikoaguliantai) buvo veiksminga, pacientès kardiovaskulinè būklè stabilizavosi ir pradèjo gerèti. Renkantis neurochirurgini plyšusios aneurizmos gydymo būdą, pirmenybè turètų būti teikiama endovaskulinei obliteracijai, tačiau, siekiant nustatyti optimalų gydymo būdą, reikalingi tolesni tyrimai [13].

Takotsubo kardiomiopatijos baigtys dažniausiai būna palankios ir pacientai pasveiksta, sistolinè disfunkcija išnyksta ir numatoma gyvenimo trukme būna panaši i bendrosios tokio amžiaus ir lyties populiacijos gyvenimo trukmę [14]. Ūminiu laikotarpiu pacientų mirtingumas yra 0-8\% [5], mirtis ligonị paprastai ištinka dèl plaučių edemos ar reikšmingo kairiojo skilvelio nepakankamumo. Vis dèlto su subarachnoidine hemoragija susijusiosios sistolinès disfunkcijos prognozė yra blogesnè [9]. Mūsų aprašomu atveju pacientès kairiojo skilvelio funkcija gydymo eigoje gerejo, tačiau dèl nutrūkusio stebejjimo galutinių duomenų apie kardialines baigtis nèra.

\section{Išvados}

Viena iš galimų Takotsubo kardiomiopatiją sukeliančių priežasčių yra subarachnoidinè hemoragija. Diagnozuojant ūmini koronarini sindromą, reikia pagalvoti ir apie stresinès kardiomiopatijos galimybę. Paprastai šio sindromo prognozė yra gera, tačiau būtinas ankstyvas diagnozės nustatymas, intervencinis kardiovaskulinių parametrų stebejjimas ir tikslinis gydymas.

\section{Literatūra}

1. Dote K, Sato H, Tateishi H, et al. Myocardial stunning due to simultaneous multivessel coronary spasm: A review of 5 cases. J Cardiol 1991; 21:203-214.

2. Bybee KA, Prasad A. Stress-related cardiomyopathy syndromes. Circulation 2008; 118:397-409.

3. M. Madhavan, A. Prasad Proposed Mayo Clinic criteria for the diagnosis of Tako-Tsubo cardiomyopathy and long-term prognosis. Herz 2010 35:240-244.

4. Lyon AR, Rees PS, Prasad S, Poole-Wilson PA, Harding SE. Stress (Takotsubo) cardiomyopathy: a novel pathophysiological hypothesis to explain catecholamine-induced acute myocardial stunning. Nat Clin Pract Cardiovasc Med 2008; 5:22-9.

5. Prasad A, Lerman A, Rihal CS. Apical ballooning syndrome (TakoTsubo or stress cardiomyopathy): a mimic of acute myocardial infarction. Am Heart J 2008; 155:408-17.

6. Nobrega S, Brito D: The "Broken Heart Syndrome": State of The Art. Rev Port Cardiol 2012, 31(9):589-596.

7. Lee VH, Connolly HM, Fulgham JR, et al. Tako-Tsubo cardiomyopathy in aneurysmal subarachnoid hemorrhage: an under appreciated ventricular dysfunction. J Neurosurg 2006;105:264-70.

8. Otomo S, Sugita M, Shimoda O, Terasaki H: Two cases of transient left ventricular apical ballooning syndrome associated with subarachnoid hemorrhage. Anesth Analg 2006; 103: $583-586$.

9. Shoukat S, Awad A, Nam DK, Hoskins MH, Samuels O, Higginson J, Clements SD Jr. Cardiomyopathy with Inverted TakoTsubo Pattern in the Setting of Subarachnoid Hemorrhage: A Series of Four Cases. Neurocrit Care. 2012 Feb 16.

10. Kothavale A, Banki NM, Kopelnik A, et al: Predictors of left ventricular regional wall motion abnormalities after subarachnoid hemorrhage. Neurocrit Care, 2006; 4:199.

11. Offerhaus, L., van Gool, J., Electrocardiographic changes and tissue catecholamines in experimental subarachnoid hemorrhage. Cardiovasc. Res. 1969; 3:433-40.

12. Wittstein IS, Thiemann DR, Lima JA, Baughman KL, Schulman SP, Gerstenblith G, et al. Neurohumoral features of myocardial stunning due to sudden emotional stress. N Engl J Med 2005; 352:539-48.

13. Inamasu J, Nakatsukasa M, et al. Subarachnoid hemorrhage complicated with neurogenic pulmonary edema and takotsubo-like cardiomyopathy. Neurol. Med. Chir. (Tokyo) 2012; 52 (2): 49-55.

14. Gianni M, Dentali F, Grand AM, et al. Apical ballooning syndrome or takotsubo cardiomyopathy: a systemic review. Eur Heart J. 2006; 27:1523-9.

\section{TAKOTSUBO CARDIOMYOPATHY CAUSED BY SUBARACHNOIDAL CEREBRAL HEMORRHAGE: CASE REPORT}

T. Janušonis, G. Klimavičiūtė, R. Paškevičiūtė

Key words: Takotsubo cardiomyopathy subarachnoidal hemorrhage, left ventricle dysfunction.

Summary

Takotsubo (stress) cardiomyopathy is a rare, non-ischemic, acute left ventricle dysfunction which is triggered by an emotional or physical stress. We describe a case of a 30 years old woman with stress cardiomyopathy caused by a subarachnoidal cerebral hemorrhage.

Correspondence to: tjmail@inbox.lt

Gauta 2013-05-17 